\title{
Innovation in mining value chains: New evidence from Latin America ${ }^{\text {is }}$
}

\author{
Carlo Pietrobelli ${ }^{\mathrm{a}, *}$, Anabel Marin ${ }^{\mathrm{b}}$, Jocelyn Olivari ${ }^{\mathrm{c}}$ \\ ${ }^{a}$ University Roma Tre, Italy and UNU-MERIT, The Netherlands \\ ${ }^{\mathrm{b}}$ CENIT, Buenos Aires, Argentina \\ ${ }^{\mathrm{c}}$ Universidad Adolfo Ibáñez, Santiago, Chile
}

\section{A R T I C L E I N F O}

\section{JEL Codes:}

O13

032

043

Keywords:

Global value chains

Natural resources

Mining

Latin America

Innovation and learning

Governance

\begin{abstract}
A B S T R A C T
The paper investigates new opportunities for innovation and linkages associated to mining activities in Brazil, Chile and Peru. Three types of opportunities were researched: demand side, supply side and local specificities. The last source of opportunities is key for natural resource related activities. The evidence shows that an increasing demand is introducing important incentives for innovation and local suppliers. Nevertheless, a hierarchical value chain, dominated by few large firms, and poor linkages is blocking the diffusion of innovations and hindering suppliers' development. The emergence of a group of highly innovative suppliers, which were identified in the three countries, is explained mostly by new technological and knowledge opportunities, which are not exploited by large incumbents and open spaces for new entrants. Local specificities are also key in the explanation of local suppliers. It remains a challenge however, how these, most of which were created to satisfy local needs, will move from local to global.
\end{abstract}

\section{Introduction}

Economic activities based on Natural Resource (NR) have expanded significantly over the past decades both in developed and developing countries. At the same time, the heavy dependence on NR has not fallen in many developing countries, raising concerns regarding the effects that these industries can have on economic development. This is not new, and has been a traditional question in development economics: are natural resource endowments a curse or a blessing for a developing economy (Sachs and Warner, 2001)?

This study focuses on the mining industry. Traditional development and innovation literatures have often offered a pessimistic picture about the development impact of NRs in general, and mining in particular (Hirschman, 1958; Prebisch, 1950; Singer, 1975). Such an opinion has been based on various explanations, for example arguing that mining is often an "enclave": "...unlike other sources of wealth, natural resource wealth does not need to be produced. It simply needs to be extracted. .... it is in a number of ways, enclaved... without major linkages to other industrial sectors" (Humphreys et al., 2007: 4).

An additional argument to support the thesis of a natural resource curse comes from the industrial organization prevailing in these sectors.
Typically, large mining operations tend to be controlled by Multinational Corporations (MNCs), which perform little local innovation, govern hierarchically their value chains, set the rules of the game unilaterally and rely mostly on foreign suppliers for key, knowledge intensive, sensitive solutions (UNECA, 2013). This is an impediment, it is argued, for diversification, local innovation and the involvement of local suppliers in the more promising stages of the value chain. In a recent survey on "Using Natural Resources for Development", Venables (2016) confirms these views but, like most of the literature, looking mainly at traditional macroeconomic arguments, such as the impact on the balance of payments, "Dutch disease" and rent seeking, and neglecting the potential offered by linkages and spillovers.

In contrast however, several recent studies within the innovation literature have questioned these pessimistic views. A new context is emerging, it is argued, which is opening new opportunities for innovation and fruitful linkages between lead firms and their suppliers, which did not exist before (Pérez, 2010; Andersen, 2012; Marin et al., 2015). These new opportunities are associated to a larger and more diversified demand for NRs, new knowledge and technology advances applicable to these sectors, and an increasing pressure to innovate to reduce environmental impact, among others (Dantas, 2011; Iizuka and

\footnotetext{
Earlier versions of this paper were presented at the Schumpeterian Society Conference 2016, Montreal, UNU-MERIT seminar in Maastricht (2016), the WIPO Mining Conference in

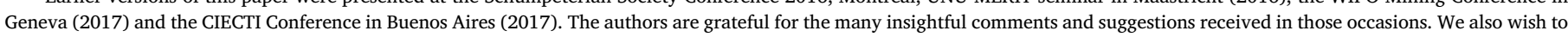

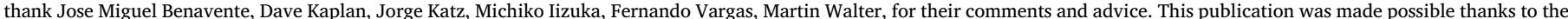

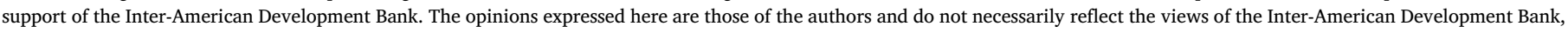
its Board of Directors, or the countries they represent.

* Corresponding author.

E-mail addresses: carlo.pietrobelli@uniroma3.it (C. Pietrobelli), a.i.marin@fund-cenit.org.ar (A. Marin), jocelyn.olivari@uai.cl (J. Olivari).
} 
Katz, 2015; Morris et al., 2012; Ovadia, 2014). Moreover, in the mining industry a tendency towards higher degrees of vertical disintegration of large producer companies, which focus more on their core capabilities and outsource other activities, has emerged in the last decades (Urzúa, 2011; Korinek, 2013; Stubrin, forthcoming). This tendency has encouraged in some cases local innovation in host countries.

However, historical evidence confirms that such opportunities do not last forever and necessarily evolve over time. The expansion of the US mining industry, during the iron and electrical power revolution, encouraged the emergence of a supplier industry of mining equipment in this country. Similarly, the Finnish mining industry spurred a metallurgic industry of suppliers, and more recently Australia has developed a huge wave of suppliers of advanced knowledge-intensive services, often based on information and communication technologies (ICT) and other scientific and technological developments (Frances, 2015, Meller and Gana, 2015; Urzúa, 2011). The mining suppliers that took advantage of technological paradigms and market opportunities prevailing at their time, now occupy important stages of the value chain. This suggests that there are windows of opportunity that open and close, and that need to be exploited timely.

This paper contributes to a better understanding of the new opportunities for innovation and linkages in the mining industry, based on original empirical evidence from three Latin American countries: Brazil, Chile and Peru. ${ }^{1}$ More specifically, we explore: (i) the nature and extent of the new opportunities for local innovation and local suppliers in mining in developing countries; (ii) the mediating role played by the organization of industry in the mining value chain (MGVC), and the extent to which it is conducive to learning and innovation in local suppliers; (iii) the nature of the firms (i.e. new startups vs. incumbents) taking advantage of these opportunities and how.

The mining sector is a very important activity for Peru, Chile and Brazil, reaching respectively $11.7 \%$, $9.9 \%$ and $1.9 \%$ of GDP, and $21 \%$, $60 \%$, and $46 \%$ of exports in 2015 . The mining sector employed $4.2 \%$ of the total in Peru, $2.9 \%$ in Chile and $0.52 \%$ in Brazil. Peru is one of the most important suppliers of a wide range of metallic minerals in the world and in 2015 it was ranked 2nd largest producer of silver, 3rd of copper and zinc, 4th of tin, lead and molybdenum. Chile's production is much more concentrated on copper, with $29.9 \%$ of world output. Brazil's mining production is extremely concentrated in iron, with sizable volumes also in niobium, vermiculite, asbestos, tantalum, and bauxite. The presence of foreign capital in Peru is critical due to its dominance in the production of copper, zinc and calcium carbonates. In Chile, the main player is the state-run company CODELCO $(31.3 \%$ of copper production), with foreign companies producing $49 \%$ of the total. The Brazilian state-run company Vale represented $74 \%$ of Brazilian iron ore sales in 2015, and in copper and nickel two foreign and two domestic companies dominate the market.

Our results suggest that some local suppliers carry out important innovative activities. They have developed advanced levels of innovation capabilities, reflected in patents, new product developments, international awards, exports of goods, services and technology, and technologies in use. However, local suppliers' innovative activity has not emerged as a result of rich linkages between the suppliers and the mining companies, as sometimes happens in GVCs (Pietrobelli and Rabellotti, 2011). Large mining companies have not built formal longterm linkages or committed to joint innovation with local suppliers, especially in Chile and Peru (Molina, 2018; Stubrin, 2018). They tend to rely on established suppliers, and when new technological challenges emerge, they either rely on solutions coming from headquarters based abroad, or on their first-tier suppliers. However, sometimes they demand technological solutions from their present or potential suppliers, and supply information about their needs, but only through informal

\footnotetext{
${ }^{1}$ Part of this evidence presented and discussed here and in other papers in this special issue was developed for a research project coordinated by two of the authors.
}

and unplanned interactions with local suppliers. Some instances of better collaboration within the value chain appear to have emerged in Brazil, with dedicated efforts to help local suppliers to surge (Figueiredo and Piana, 2016, 2018), but evidence is not conclusive. Our evidence also suggests that, in most cases, the costs and risks of seeking new technological solutions and offer new services and intermediate products have been entirely borne by the successful firms, with limited involvement of chain-leaders. One of our conclusions is therefore, that incentives to innovate in our cases have not derived from interactions with large clients, but mostly from new knowledge and technological opportunities (e.g. new IT and biotech advances) and the idiosyncratic nature of NRs, that often requires locally developed solutions.

Our evidence also suggests that if these successful experiences were to expand to large numbers of local suppliers, the capabilities required to go from local to global would go far beyond the scientific, technological and production-related capabilities. The need to commercialize the results, and to enter in fruitful bargaining processes with chain leaders and large mining firms (and their first tier of suppliers) have often been missing in the cases studied and are in strong demand. An additional conclusion of our cases is thus, that potential suppliers need to thoroughly understand the logic of operations of MGVCs, and to strengthen the capabilities complementary to production and innovation to succeed. These include the capacity to develop the non-technological assets required to exploit their scientific and technological capabilities, in a framework where large mining companies are not investing in these linkages and in joint innovation and where systematic policies oriented to support emerging innovators appear to be lacking.

The paper is organised as follows. First, we present the research background. Two main issues are highlighted: first, the importance of new technological and market opportunities for understanding the potential for innovation and upgrading in mining activities; second, the different types of opportunities emerging from the demand and the supply side. In the second section, we discuss key features of the methodology and empirical approach. The evidence is presented in a third section, where we explore the nature and extent of new opportunities for innovation, and we discuss the main barriers to innovation and upgrading faced by the suppliers studied. A final section concludes by analysing research implications and policy insights derived Ville and Wicken, 2012.

\section{Theoretical background}

Can innovation help reverse the resource curse so often claimed to apply to developing countries (Venables, 2016)? The innovation literature recognizes demand and technology as the two main sources of opportunity for innovation. These change across industries and over time. In NRs, the literature has also identified a third source of opportunities for innovation: local specificities, which are an incentive to innovation at the local level to the extent that solutions developed in one context may not work in another. These different types of opportunities may create a fruitful context for innovation, that firms may exploit provided they have the necessary capacities based on their resources, knowledge and competence. These ideas are discussed in the rest of this section.

\subsection{Demand opportunities}

\subsubsection{Demand size}

The size and quality of demand may be important for innovation. Schmookler (1966) was the first to emphasize the importance of the size and growth of the market for innovation. He claimed that firms that innovate more are those that induced by a large and increasing demand, make more use of the fixed common pool of existing knowledge by making their own complementary investments in applied R\&D. They will do so because the expected benefits associated to the costs of R\&D will be larger. More inventive activity would therefore be expected in 
the larger of two markets, and in the one that is expected to grow more rapidly.

Interestingly, this increased demand in the mining sector creates incentives for innovation not only because of the larger expected benefits associated to R\&D but also because of the exhaustion of resources and deposits of good quality - under the assumption that also natural resources are scarce, sooner or later - forcing producers to look for new deposits and new methods. What happened in the late nineteenth century is an example of the importance of this driver. The demand for copper increased significantly and companies faced a gradual exhaustion of high-grade ores. This forced the adoption of new techniques to find, prospect, remove ores, to improve work organization and ore processing. More powerful machinery and power sources became common as mechanical and electrical power largely replaced steam, animal and manual power, which in turn enabled deeper mines and larger production scale. New converters, furnaces, ore dressing- and smelting techniques permitted the utilization of lower grade ores (Singer, 1950). In this sense, the significant increase in the demand and prices of minerals over the last decades, reflecting the unprecedented growth in the demand from China, India and other emerging economies, and a lag in minerals and metals supply (ICMM, 2014a; Farooki, 2012), would represent a powerful inducement to innovation. ${ }^{2}$

\subsection{Demand for quality and interactions}

More modern views have stressed the importance of the quality of demand and users' knowledge for the development of new products and processes, with the interactions between those that develop and those who use innovations playing a crucial role, especially in a context of high uncertainty (Lundvall, 1988, von Hippel, 1976). Interactions between clients and users can take very different shapes. Global value chain (GVC) studies have investigated the different kinds of interactions that emerge in the presence of large clients, and the power the latter have over the rest of the actors that participate in the chain. This literature is therefore particularly relevant for mining, where buyers are large and powerful and usually set the standards and performance parameters under which all actors have to operate (Farole and Winkler, 2014: 199-120). In this regard, GVC literature has established that usersuppliers interactions within GVCs can both encourage or limit learning and innovation depending on the kind of governance that prevails. In addition, opportunities for learning and innovation within GVCs will be affected by the characteristics of knowledge (in terms of its complexity, cumulativeness, codifiability and appropriability) (Pietrobelli and Rabellotti, 2007), channels of technology transmission (technical assistance, labor mobility, licenses, etc.) and the firms' differences in absorptive capacity (Gereffi et al., 2005; Morrison et al., 2008).

The combination of these factors has led to many GVC governance classifications (Gereffi et al., 2005), each with different implications for suppliers' learning and innovation (Pietrobelli and Rabellotti, 2011). For example, in captive-type chains with low competence of suppliers and highly codified transactions, a situation where the support of lead firms is confined to a narrow range of tasks related to simple assembly is likely to prevail. Local firms' learning and upgrading would be influenced only by own efforts, and the interactions with the lead firm would not foster the process, but only set a requirement to comply with (Pietrobelli and Rabellotti, 2011).

In mining GVCs hierarchical forms of governance tend to prevail (Morris et al., 2012), due to the complexity of information involved in the transactions between the lead firms and its suppliers, the often tacit and local knowledge involved and the huge size and related economies of scale enjoyed by the lead mining firms, that produce often asymmetric power relations in the chain. With the tendency towards vertical

${ }^{2}$ In 2012 the global value of mineral production was over six times higher than in 2000 (Stubrin, 2018). disintegration and local outsourcing prevailing in the mining sector since the 1970s, the opportunities for local outsourcing and learning increased. Indeed, large mining houses began to concentrate on their core capabilities and outsource the rest of the activities (Morris et al., 2012, Fessenhaie, 2012), opening new opportunities for new intermediate goods and services suppliers. However, the hierarchical governance prevailing in most MGVCs would lead us to expect that the suppliers' learning opportunities face serious constraints.

An apparently contrasting evidence from countries such as the US, Australia, Canada and South Africa, would suggest that KnowledgeIntensive Mining Suppliers (KIMS) have emerged strongly, and they would be responsible for most innovative activities in the mining industry (Crespi et al., 2016; Cutler, 2012). ${ }^{3}$ Nevertheless, the general evidence prevailing in Africa and in other developing countries (see Molina, 2018; Molina et al., 2016 on Peru, Kaplan, 2012, Kaplinsky and Morris, 2016, and ECA, 2013) suggests that large mining companies still rely mostly on foreign suppliers for key, knowledge intensive, sensitive solutions.

\subsection{Local specificities}

No two mineral deposits are the same, so each operation needs particular inputs and tailor-made solutions. Under these circumstances the automatic application of standardized solutions cannot always work well, and companies are forced to innovate to look for new localized solutions. This opens opportunities for innovation and the development of domestic suppliers to address location-specific demands and requirements.

In South Africa the presence of poor quality coal deposits with many impurities led to the development of advanced technological capabilities in the washing of coal (Pogue 2008). In Australia ores with complex mineralogy, and hot and dry conditions encouraged the development of locally adapted solutions and suppliers (OECD, 2005, Scott-Kemmis, 2013). Something similar happened in the US, where open pit mining technologies were developed to face low grade ore bodies, which were decreasing more rapidly compared to other mining countries.

We expect that in the case of the countries analyzed in this study, local specific environmental conditions, such as high altitudes of the mines and the dry weather, will represent a powerful incentive for local innovations, since in general mining activities in other countries are not performed at high altitudes.

\subsection{Supply and technological opportunities}

The innovation literature links differences in the rate and direction of innovation also to supply side factors, called "technological opportunities" (TO). These are the opportunities for innovation deriving from advances in the knowledge bases and their technical applications, and explain the easiness with which companies in a particular industry obtain innovations given the amount of financial resources invested (Laursen, 1999; Klevorick et al., 1995). Three sources of TOs have been identified by existing studies: (i) advances in scientific understanding, which would increase the problem-solving capacity of professional workers and produce knowledge in applied sciences and engineering responding to specific problems in the industry; (ii) Technological advances generated outside the industry by other value chain firms (e.g. advances in new materials and in biotechnology fostered innovation respectively in aerospace and in the food industry); (iii) Feedbacks from technology, when the learning used to solve a particular problem can be used in the same industry to solve new emerging problems.

\footnotetext{
${ }^{3}$ Four kinds of KIMS have been distinguished: KIMS Consultants, Specialized Services Contractors, Capital Goods and Equipment Suppliers and Consumable Inputs Suppliers (Urzúa, 2011).
} 
Existing studies have documented how recent advances in knowledge have opened new technological opportunities for innovation in NRs in general (Marin and Petralia, 2018), and in the mining industry in particular. These are related to the massive advances in information and communication technologies (ICT) and other areas of knowledge (Pérez, 2010; Marin et al., 2015). In the case of mining in particular, related to the applications of these new technologies a process of technological rejuvenation is taking place (Urzúa, 2011). Some examples include advances in ICT and computer vision systems which are allowing among other things: better understanding about materials, new forms of communication and tailor-made solutions in smaller batches (3D printers). ICT has also helped in developing satellite and other remote sensing applications which have led to deposits being found much more quickly and to accurate mapping of a wide range of geological attributes at dramatically reduced costs.

Moreover, advances in molecular and in synthetic biology are allowing mining processes such as bioleaching and bioremediation for copper and gold, which make the process of mineral extraction more efficient, and in some occasions also changed the feasibility of investment projects (Segal, 2000). For example, taking advantage of the new possibilities opened by biotechnology, a new technique is being developed named biolixiviation, which consists of using bacteria to obtain copper from low grade ores which cannot be exploited by traditional methods. This technology is more environmentally friendly than traditional methods. In Chile, around $10 \%$ of copper is currently obtained by biolixiviation (Benavente and Goya, 2011; Marin and Van Zwanenberg, 2015)).

In sum, local suppliers could take advantage of the new technology and knowledge opportunities to enter the more knowledge-intensive segments of the value chain. They can get access to this new knowledge from different sources and through different processes (i.e. R\&D cooperation agreements with other firms or research centers). The more location-specific this knowledge is, the less likely it is that lead firms and buyers can act as effective conduits for such knowledge. However, some forms of governance of the GVC will encourage, facilitate or sometimes limit access to these new knowledge and technological opportunities. Thus, sometimes incentives to favour collaboration between lead-firms and their suppliers may exist, especially when less hierarchical forms of GVCs prevail (Pietrobelli and Rabellotti, 2007), and lead firms do not demand compliance to exact requirements and standards, but also support the related learning, knowledge acquisition, and technological development.

\subsection{Firm's capabilities and strategies to exploit technological opportunities}

Not all firms or new ventures, however, will have the ability to take advantage of these opportunities arising from the demand or the supply side. The innovation and business literature has pointed out the importance of firm's strategies and micro behaviors for the creation and exploitation of innovation demand and technological opportunities (Nelson and Winter, 1982; Teece et al., 1997). Firms have to develop technological capabilities or the capabilities to create, change or improve products, processes and production organization, and equipment. Technological capabilities are 'the resources (knowledge base) to manage and generate technological change'(Bell and Pavitt, 1993), and they are not acquired as an automatic by-product of firms' investment and production activities (Lall, 1992), but accumulated through a process of technological learning.

Learning can also occur through the interactions within GVCs, where lead firms can propose (impose) fast learning to comply with their requests and standards, or sometimes can support learning processes through explicit and purposeful actions, whenever the learning outcome represents a mutual advantage and the costs of switching to alternative providers is high. ${ }^{4}$

However, some of the key dimensions for technological learning and

\footnotetext{
${ }^{4}$ A classification of possible learning mechanisms within GVCs has been proposed recently by Pietrobelli and Rabellotti (2010 and 2011).
}

innovation identified by the existing literature (e.g. R\&D, skills, and linkages with other actors) might not be enough for firms that have already developed new solutions but may still lack the GVC management and integration capabilities, and the market creation capabilities, which are crucial to sell and take full advantage of their innovations. ${ }^{5}$ In these cases markets do not yet exist for unique solutions based on new knowledge, and firms have to create a new market, convince a (often) monopsonistic buyer, obtain license to experiment with the new technology, define the space and conditions for the transaction i.e. agree on the value, establish the rules of the game, negotiate the distribution of benefits. In our specific cases of MGVC the issue could be for instance the discovery of the specific niche, and the demand for a solution (i.e. service or intermediate product) needed by larger firms and leaders in different tiers of the MGVC.

From existing studies, we know for instance that it is difficult to put a price on intangible assets whose performance features are difficult to ascertain (Marin et al., 2016). Knowledge providers need to develop capabilities to negotiate with large buyers the value of their services and win their resistance and preference for incumbents. The difficulty to convince GVC clients (i.e. chain leaders and 1st tier firms) to try new things, to sell the new ideas and to obtain access for experimentation is often notable (Molina, 2018). ${ }^{6}$ The literature has acknowledged the importance of complementary assets for exploiting innovations and new knowledge in mass markets in advanced countries (Teece, 1986; Marin et al., 2016). However, little is known on the capabilities to sell and interact with what are often giant mining companies in developing countries.

\subsection{In Sum}

We understand therefore that there is a new potential for providers in the mining industry that derives from demand, local specificities and technological opportunities and from the active attitude of local innovative suppliers that invest in technological and non-technological capabilities to enter MGVCs.

The prevailing industrial organization may hinder this process, as large MNCs tend to privilege very well known, standardised, modular solutions, and thereby simplify contracts and reduce transaction costs. They also prefer to rely on well-known reliable suppliers to deliver solutions to their problems to reduce uncertainty, disruptions in the mining value chains, and additional problems and costs. However, the pressures for change are significant. The historical circumstances are creating new room for new entrants developing many of the services demanded by the mining industry. Local suppliers from emerging countries can be in a privileged position to occupy these new spaces, and develop the opportunities opened by the new discoveries in ICT, biotechnology, new materials and other sciences. Moreover, the rising demands from the imperative of green growth and social sustainability are also creating new market spaces (Katz and Pietrobelli, 2018). Entrepreneurial action is favored by the ambiguity of nascent markets.

\section{Methodology and sources}

In this paper we use the secondary evidence derived from a recent project that two of the authors directed, and that also supported the other papers published in this Special Issue, as well as other related papers. ${ }^{7}$ The method followed in these studies is essentially a firm-level multiple-case study research (Yin, 2009). A key aspect of this kind of design is the selection of cases, which have to be representative of the

\footnotetext{
${ }^{5}$ This has been shown to apply to several NR suppliers (Marin et al., 2016).

${ }^{6}$ The difficulties of providers to enter certain segments of the activity have been explained for Chile by Urzúa (2011) and Stubrin (2018), and for Peru by Molina (2018).

7 The project was financed by the Inter-American Development Bank. The opinions expressed here are those of the authors only and do not necessarily reflect the views of Bank.
} 
Table 1

Mining suppliers studied: basic information.

\begin{tabular}{|c|c|c|c|c|c|}
\hline Firm & Year founded & $\begin{array}{l}\text { Capital (Foreign, } \\
\text { National) }\end{array}$ & Main product & $\begin{array}{l}\text { Innovation novelty (new } \\
\text { to:) }\end{array}$ & Patents \\
\hline \multicolumn{6}{|l|}{ PERU } \\
\hline Bisa & 1977 & $68 \% \mathrm{~F}$ & Exploration, planning and consulting & company & \\
\hline Exsa & 1956 & National & Exploration, planning and consulting & world & 9 \\
\hline Ferreyros Corp & 1922 & $35.8 \% \mathrm{~F}$ & Extraction & local mkt & \\
\hline Resemin & 1989 & National & Extraction & world & 4 \\
\hline Tumi Raise Boring & 1982 & $65 \% \mathrm{~F}$ & Extraction & world & 1 applied \\
\hline Fima & 1969 & $33.1 \% \mathrm{~F}$ & Mining spool & local mkt & \\
\hline UTEC & 2012 & Non-profit & Research & local mkt & \\
\hline TECSUP & 1984 & Non-profit & Metallurgical research & local mkt & \\
\hline \multicolumn{6}{|l|}{ CHILE } \\
\hline Neptuno Pumps & 1972 & National & Water pumps & world & 2 applied \\
\hline JRI & 1982 & National & Engineering projects & world & 6 \\
\hline Drillco Tools & 1990 & National & Hammers and drills & world & 3 \\
\hline High Service & 1999 & National & $\begin{array}{l}\text { Products and services to SAG mills based on wireless } \\
\text { technology }\end{array}$ & world & 3 \\
\hline Aplik & 2001 & National & Products and services to increase mining efficiency & world & 10 applied \\
\hline MICOMO & 2006 & National & $\begin{array}{l}\text { Monitoring services and environmental forecasts for mining } \\
\text { operations }\end{array}$ & world & 2 \\
\hline Aguamarina & 2007 & National & Biotechnological products and services & world & 3 \\
\hline Power Train Technologies & 2007 & National & Engines, remote control systems and repair & world & \\
\hline Innovaxxion & 2012 & National & New products and services to increase efficiency in foundries & world & 18 applied \\
\hline \multicolumn{6}{|l|}{ BRAZIL } \\
\hline Sigma & 1994 & National & Geotechnology & local mkt & \\
\hline Gamma & 1988 & National & Environment management & local mkt & \\
\hline Beta & 2007 & National & Geotechnology & local mkt & \\
\hline Kappa & 2004 & National & Components and equipment & local mkt & \\
\hline Alpha & 2004 & National & Consulting (environment) & world & 1 \\
\hline
\end{tabular}

Source: Case studies from Molina (2018), Molina et al. (2016), Stubrin (2018), Figueiredo and Piana (2016, 2018) and Navarro (2018).

Table 2

Lead mining firms (buyers): Basic Information.

\begin{tabular}{|c|c|c|c|}
\hline Firm & $\begin{array}{l}\text { Year } \\
\text { founded }\end{array}$ & Capital & Main product \\
\hline \multicolumn{4}{|c|}{ Peruvian Mining Companies } \\
\hline Antamina & 2001 & $100 \% \mathrm{~F}$ & $\begin{array}{l}\text { Copper, silver, lead, } \\
\text { molybdenum }\end{array}$ \\
\hline $\begin{array}{c}\text { Southern Copper } \\
\text { Corporation }\end{array}$ & 1954 & $100 \% \mathrm{~F}$ & Copper, molybdenum \\
\hline Yanacocha & 1992 & $51.35 \% \mathrm{~F}$ & Gold, silver \\
\hline El Brocal & 1956 & $51.36 \% \mathrm{~N}$ & $\begin{array}{l}\text { Silver sulfide, lead, zinc, } \\
\text { copper }\end{array}$ \\
\hline AngloAmerican & 1999 & $100 \% \mathrm{~F}$ & Copper \\
\hline Milpo & 1949 & $45 \% \mathrm{~N}$ & Zinc, lead, copper \\
\hline \multicolumn{4}{|c|}{ Chilean Mining Companies } \\
\hline Codelco & 1971 & $100 \% \mathrm{~N}$ & Copper, nickel, lead, zinc \\
\hline BHP Billiton & 1984 & $100 \% \mathrm{~F}$ & Copper \\
\hline Minera San Gerónimo & 1963 & $100 \% \mathrm{~N}$ & Copper, silver, gold \\
\hline \multicolumn{4}{|c|}{ Brazilian Mining Companies } \\
\hline Vale & 1942 & $100 \% \mathrm{~N}$ & $\begin{array}{l}\text { Iron ore, manganese, copper, } \\
\text { nickel, phosphate, potassium }\end{array}$ \\
\hline
\end{tabular}

Source: Case studies from Molina (2018), Molina et al. (2016), Stubrin (2018), Figueiredo and Piana, (2016, 2018) and Navarro (2017).

phenomenon we are interested in, rather than randomly drawn from a population; the sample is therefore purposive, where exemplary cases are identified. The studies carried out for the project, based on detailed interviews to firms and key informants from the public sector, universities and consultancies, selected the most innovative local suppliers in each context. Table 1 gives an idea of the basic features of these firms, that supply a variety of mining lead firms (Table 2).

Information was collected through non-structured interviews to key informants, from government and firms and, a structured survey to suppliers and clients. In order to ensure data triangulation, information was collected from multiple sources within and outside the examined firms (Yin, 2009). Thus, qualitative and quantitative data were combined.

Thirty-six in-depth interviews were conducted with managers, engineers and R\&D personnel of the selected companies. The fieldwork was conducted between April and July 2016. The survey to suppliers captured general information about the firm, characteristics of the products and processes, technological capabilities, linkages with other firms and institutions, and obstacles to innovation. The survey to clients asked about the main suppliers, and policies and practices used to select and interact with suppliers

\section{Empirical analysis}

In the next section we explore the theoretical hypotheses discussed above in light of the original evidence gathered for this special issue and elsewhere. We first discuss opportunities deriving from the demand and local specificities, and then technological opportunities. Then we analyze firm level strategies and behaviors, and the kind of capabilities that are being developed.

\subsection{Where the incentives for innovation come from}

\subsubsection{Incentives coming from demand}

The mining activity faces important challenges in all the countries analyzed. These are related to four main factors: (i) decreasing grade ores (recovery rates of minerals); (ii) changing local environmental conditions; (iii) decreasing productivity and increasing costs; (iv) rising social and environmental problems. Grade ores have decreased significantly in copper production in Chile, from $0.95 \%$ to less than $0.7 \%$ (Cochilco, 2010). In Peru Antamina reported a decrease in ore grades from $1.6 \%$ to $0.8 \%$ in only one year, and the forecasts are even worse for the near future (Molina et al., 2016). McKinsey (2013) estimates that ore grades in Peru will decrease 19\% on average between 2012 and 
2025 , more or less in line with the world average (21\%).

The best locations for mining activity in Brazil, Chile and Peru have in general already been exploited. The increased demand for minerals over the last two decades has forced mining companies to look for new locations, which present new challenges due to the different local geographical conditions under which the mineral has to be extracted. In Peru for instance, due to the depletion of clean deposits, mining companies are working with deposits of copper, silver and gold exposed to high degrees of "dirty" minerals such as arsenic and sulphur (Molina et al., 2016). Moreover, mining activity in both Peru and Chile is performed at high altitudes, and in narrow veins. The La Rinconada mine, in Puno, at $5100 \mathrm{~m}$ above sea level, is the highest in the world (Molina et al., 2016) and similar conditions prevail in Chile. Existing equipment and solutions underperform, and there is a need to adapt them or develop new ones (Glade and Kuramoto, 2007). Similarly, in Brazil most of the activity has been moved to deeper mines, where the treatment of the mineral is more complex (Figueiredo and Piana, 2016). These conditions pose remarkable demands for innovation.

The decrease in workforce productivity that the sector is facing is partly a reflection of these problems. In Peru workforce productivity has decreased by $30 \%$ since 2005, and 24\% in Chile between 2005 and 2013 (Molina, 2018; Cochilco Yearbook, 2015). Brazilian firms, and notably Vale, are also struggling to improve productivity in the recent years of falling global demand and rising costs due to difficult access to work, water and energy. In Chile mining costs have increased $111 \%$ between 2005 and 2014 (Stubrin, 2018), also due to the highest cost of water in the world, similarly to Peru, as sea water needs to be carried to the high altitude mines.

Finally, social and environmental challenges are becoming a central issue for mining companies. $31 \%$ of recent mining projects in Chile were postponed due to conflicts with local communities and environmental problems (Stubrin, 2018), and in Peru, 140 environmental and social conflicts were recorded between 2012 and $2014 .^{8}$ Local communities are concerned about livelihood security, environmental degradation and the perception that the wealth created is not fairly shared. Governments react by introducing more stringent environmental regulations and requiring some local involvement in decision making (Katz and Pietrobelli, 2018). Again, the demand for innovative solutions and sustainable methods of production is rising fast.

These important challenges could offer important opportunities for innovation in the industry. However, large mining companies need to transform these challenges into concrete demands for innovation for local suppliers and they often fail doing it for multiple reasons. Codelco, the large state-owned Chilean copper company, for instance, announced that only $16 \%$ of the problems that they identified between 2010 and 2012 had been further developed and translated into announcements and concrete demands to potential suppliers (Fundación, 2014; Fundacion Chile, 2014, Bravo-Ortega and Munoz, 2015). And, even when announcements are done, and local suppliers are selected to provide a solution, the quality of the linkages between mining companies and their suppliers does not seem to be supporting innovation in suppliers, because the relationship is often informal and hardly continues after the first contact and exchange of information (Navarro, 2018; Stubrin, 2018; Molina, 2018). Substantial opportunities for mutual learning are being wasted.

One of the problems derives from the very hierarchical structure of the value chain characterized by important power and resources asymmetry (Arias et al., 2014). This is not surprising given the massive concentration around a few companies that hold most of the purchasing power in the sector. In Chile for instance, only two companies, BHP and Codelco, respectively multinational and domestic, account for $50 \%$ of copper production. In Peru, four large MNCs account for $79 \%$ of mining production (Antamina, Southern Peru Copper Corporation, Cerro Verde and Antapaccay) (Molina, 2018). In Brazil, Vale alone produces $52 \%$ of total mining volumes (Figueiredo and Piana, 2018).

This kind of structure is associated in the literature to poor quality of knowledge linkages, and our findings confirm this idea. In general, we identified linkages with very poor potential to encourage innovation in MGVCs. From the interviews emerged that the large mining companies analyzed are in general very resistant to try new solutions that have not been tested worldwide. They demand successful pre-testing conducted in several mines before even trying it, particularly when the solution comes from domestic suppliers. In Peru, it has been detected that the communication channels with the lead mining firm are only available for suppliers that are already working with the mining company (Molina, 2018). Aside from open tenders, there are no formal channels through which new suppliers can gain access to mining companies. It is suppliers themselves that need to incur in the transaction costs needed to approach the mining companies and offer their services, and often lack these capabilities.

When lead firms announce a problem, and decide to involve local suppliers, as it is often done in Chile (Navarro, 2018), they do not get involved in the R\&D process once the supplier is selected. Suppliers develop or adapt the solutions (i.e. a machinery, tool or a service) by themselves, take all the risks, and carry out most of the investments. Also, it is common practice to use very short-term contracts, of one or two years maximum, though longer for engineering services. These practices obviously restrict the possibilities of domestic, usually small, suppliers to commit to innovation, which is an activity by definition with uncertain results.

Some of the examples reported for Chile illustrate the characteristics of the process of interaction between mining houses and suppliers (Stubrin, 2018). The process usually appears to occur like this: a mine, for example Centinella, owned by Antofagasta Minerals, calls a known supplier, e.g. Aguamarina, to address a specific problem. A concrete problem identified was, for instance as reported in the interviews, that the pipeline that the company was using to transport seawater was getting perforated. Aguamarina, based on its biotech expertise discovered that the problem was related to bio corrosion and delivered a tailor-made solution developed entirely by the supplier, with no R\&D intervention by the large mining company. Similar processes were described in the cases of Aplik, a supplier that responded to a demand from the clients, and spent a year in the mining company trying to understand the nature of the problem. ${ }^{9}$ A similar pattern has been identified in Peru, with workers of suppliers spending considerable time in the large mining companies in order to identify problems, but then developing the solutions by themselves (Molina et al., 2016).

In sum, at least for Chile and Peru, our results confirm that exchanges of information within the MGVCs happen, but they are mainly informal, and mostly focused on the identification of the problem, rather than on finding a solution. Indeed, few exchanges were reported during the R\&D stage. This is an impediment that is especially stringent for newcomers, which are unknown by the lead companies, and for the development of riskier and larger innovations, which require significant investments in infrastructure and knowledge on the side of suppliers, forced to bear all the costs and risks.

The experience of Brazil seems to suggest partly different conclusions. Figueiredo and Piana, (2016, 2018) found evidence of rich "learning linkages" between Vale and its suppliers, as well as between Vale, some Brazilian Universities, and sometimes firms from different industries (e.g. Petrobras). They report that from 2009 to 2012 Vale developed $161 \mathrm{R} \& \mathrm{D}$ projects with universities (151 of them from Brazil) with an estimated value of about USD 88.8 million. In some instances, it appears that Vale encouraged the development of learning linkages
${ }^{8}$ The Peruvian Institute of Economics estimated that US $\$ 21.5$ billion have not been invested because of these conflicts (Molina, 2018).

\footnotetext{
${ }^{9}$ Similarly, Innovaxxion explored the refineries of Codelco to try to find solutions for several problems faced by the mining company.
} 
between other MNC subsidiaries and local mining suppliers, for example with regard to the development of belts to transport iron ore (Figueiredo and Piana, 2016:140). Important learning linkages also occurred with public R\&D centers and sectorial institutions. For instance, with the Mineral Resources Research Company (CPRM), a government organization that seeks to generate and disseminate geological and hydrogeological knowledge in Brazil. Later on the company made an agreement with Google and became its main Brazilian partner (Figueiredo and Piana, 2018). How to explain the difference with Brazil? The authors argue that this may have been due to the social ties and cooperative behavior among industry partners, and to a "relational embeddedness" (Figueiredo and Piana, 2016: 412). This would not reflect Vale's corporate policy however, but rather individual managers' attitudes to act as facilitators of innovative collaborations.

Some of the companies studied, such as BHP Billiton and Codelco, in Chile and, Antamina, in Peru, have implemented specific programs communicate challenges to potential local suppliers and create a market for solutions. An open competition for solutions is then started, and the selected suppliers are supported to develop the solution. An interesting aspect of both programs is that they involve academic institutions as partners for the development of solutions. In Chile Fundación Chile, a public/private foundation that promotes innovation and entrepreneurship in the country acts as a broker in the process. Both programs claim to be oriented to support innovation in suppliers, by providing them with training and knowledge exchanges, and most importantly testing and experimentation spaces. The World Class Suppliers Program (WCSP) in Chile, is even more ambitious since it has among its aims to encourage scaling up of the innovative outcomes offered by suppliers and foster increasing participation into international markets.

Nevertheless, the information collected from our interviews and other authors' research, suggests that not many significant results have been obtained by these programs. The programs seem to be working at the best as an efficient tool to reduce information asymmetries (Navarro, 2018). However, they still fall short from creating a framework for the development of cooperative linkages between large mining companies and local suppliers supporting innovation. Indeed, the terms of the contracts established between the large mining companies and the suppliers are confidential and vary from case to case, and interviews with some participants indicate that they are not significantly different from those established with suppliers out of the program. The selected suppliers receive some financial support to develop their solutions, usually in the form of purchase orders, but the research to develop the solution is managed by them alone, with no significant knowledge support from the lead firm. Moreover, funding of these programs is still limited, and they have reached only a reduced number of suppliers. In Chile they were 100 out of 6000 mining suppliers; in Peru 250 (Molina, 2018, Navarro, 2018).

A proof of the limited reach of the programs in supporting really innovative solutions is the length of the projects, between 15 and 27 months (Fundación Chile, 2012). Much longer-term relationships are necessary however for the development of creative solutions. The intellectual property rights (IPR) eventually generated stay with the supplier firm, but this does not appear to be very effective, due to the difficulties encountered in commercial exploitation.

In sum, demand-side innovation incentives through the linkages within the MGVCs, in the best of the cases, in association with programs as the ones described or informal contacts, provide information, standards and detailed information about challenges and current problems, but little concrete support for innovation. In Brazil there is evidence some evidence of learning through interactions between clients and local suppliers, but the final results are not significantly different. MGVC leaders tend to discourage the search for original solutions and rather rely on foreign established providers; they foster competitive processes among suppliers to have them run and offer the best solutions - but they do not promote joint innovative and other efforts, they share very little risk and let small local firms undertake all the pre-competitive investments to eventually offer a useful solution to a local problem. Possible better drivers of innovation could for example include opening the mine to potential suppliers and partners for experimentation, setting up facilities for research and experiments, collaborating with more than one potential supplier and opening access to the solution to more than one firm. This does not appear to be happening.

\subsubsection{Incentives to innovation coming from the supply side}

Supply side incentives seem to be more effective in MGVCs. Our evidence shows how several suppliers managed to enter the MGVCs taking advantage of the new opportunities opened by changes in scientific knowledge and technologies applied to mining (Bravo-Ortega and Munoz, 2015).

Changes and opportunities opened by the ICT revolution are an important source of opportunity to develop both completely new products and adapt old ones. The company Micomo, from Chile, for instance, developed highly innovative monitoring technologies through optical fiber that help extraction processes, and obtained two patents and one international award (Stubrin, 2018). Power Train technologies entered the market with new remote control systems for trucks that operate at very high temperatures, required for performing mining at high altitudes. High Service from Chile obtained three patents related to remote monitoring and wireless communication which allows predicting wear points for key equipment, and in this way anticipate replacements and avoid to stop operations, which costs around USD 150 thousand per hour. Geoambiente, from Brazil, entered the MGVC developing sophisticated geological maps, sensors and radar images that help in the exploration phases, predicting contents of minerals and areas or erosion and are useful to monitor environmental impact (Figueiredo and Piana, 2018). The innovativeness of the company made it the largest Google partner in Brazil and helped it diversify into markets and countries beyond mining.

Another important area of new knowledge opportunities that companies are exploiting is new materials. Neptuno from Chile, for instance, developed pumps for one of the biggest open-pit mine in the world, adapted them to operate at $4500 \mathrm{~m}$ above the sea levels by upgrading materials, incorporating superior alloys and advanced engineering thermoplastic and extending the life of pumps. This gained Neptuno ten national and three international awards. One company from Brazil became a supplier of Vale developing new metal alloys, with longer durability at high temperatures (Figueiredo and Piana, 2018). Using the same kind of opportunities, Verti from Brazil developed dust suppressants that use glycerin left over from biodiesel plants, and new technological routes to recycle materials and to treat waste water. Aplik from Chile has entered the MGVC exploiting the technological opportunity offered by robotics. One of the main innovations of the company is a new tool for controlling irrigation at key parts of the process, helping to detect failures through irrigation maps and an alarm system. This new system is in the process of being patented and has received several national and one international award (Stubrin, 2018).

In one of the cases, we also found what it seems to be a very promising area: the application of biotechnology to make the mining process more efficient and clean. Aguamarina is a pioneering Chilean company that managed to enter the value chain by developing first bioleaching (i.e. the extraction of metals from their ores through the use of living organisms), and then expanded into new product lines, all biotechnology-based solutions for mining companies. The main areas of activity of Aguamarina are biolixiviation, biocorrosion, biorremediation, biorreactors, water treatment and dust control (Benavente and Goya, 2012). For example, Aguamarina created unique solutions for dust control based on bacteria and microalgae. This was a new solution for a long-dated and crucial problem as mining operations create enormous amounts of dust that affect the environment, the maintenance of the machinery, and even the health of mine workers and inhabitants of nearby communities. The company obtained three patents in the 
USA, and won five national awards.

The integration of many areas of knowledge also creates opportunities for the development of completely new or adapted products. Neptuno develops novel, innovative pumps combining knowledge about new materials, chemistry, engineering and 3D printing; Innovaxxion developed the new technology denominated Earless which reduces from $20 \%$ to $10 \%$ scrap in the copper mining process by integrating knowledge about mechanical engineering, robotics and electrical engineering; Aplik integrates knowledge about electronics, informatics, mechanics and metallurgy, Geoambiente's unique results derive from combining traditional knowledge about geology with new knowledge related to communication.

A different form of integration and innovation may also occur when new combinations of existing knowledge and technologies are used to improve and upgrade existing tools and machinery. For example, Exsa in Peru, combining knowledge about engineering, explosives, new materials and chemistry developed a new method of rock fragmentation (Quantex) that generates savings of up to $20 \%$ of total costs and has positive environmental impact. The technology has been patented in Peru and the US (Molina et al., 2016). Resemin developed special jumbos for narrow veins, and for coping with extreme environmental conditions of underground mining in Peru by combining different elements of knowledge about metalworking, geology, engineering and IT (Molina, 2018). Some of the jumbos developed by the company, like the Muki, are now patented in the US. ${ }^{10}$ Although largest mining suppliers have developed drilling jumbos to operate in these veins, they have faced limitations to run in sections of $1.8 \mathrm{~m}$ width or less, and this has never been the top priority for these suppliers. Narrow veins is an important niche market that Resemin took advantage of when they introduced the Muki. This also meant increased mining productivity, drilling a $2.4 \mathrm{~m}$. hole in $40 \mathrm{~s}$, unlike traditional methods which take seven minutes, and mechanization in tunnels, which improves safety of the operators (Molina, 2018).

This latter example highlights another general result of our studies: technological opportunities appear to have been exploited mainly in areas where the need cannot be met (or is not convenient to meet) by more experienced multinational suppliers. One of the reasons why large incumbent suppliers do not entry these niches is because they often require locally adapted solutions.

\subsubsection{Local suppliers strategies and capabilities}

Although new demands for innovative solutions as well as technological opportunities have emerged in the mining value chains analyzed, only few firms have managed to fully exploit them and successfully integrate into MGVCs. It is therefore of utmost importance to try to understand which kind of strategies these firms have followed and the main limitations they have faced, in addition to the nature of the governance of the MGVC, that acted as a mediating factor as discussed above.

From our analyses, it appears that two kinds of domestic firms are taking advantage of the emerging technological opportunities: incumbents, with a trajectory in the market, and new ventures of different kinds, including spinoffs from Universities and other science-based ventures. These two types of firms use two very distinctive strategies to enter the high-end segment of the value chain (Stubrin, 2018). The incumbent firms are in general improving existing solutions (products or services) to old problems, very often taking advantage of local specificities. The new ventures aim at opening new segments, developing new products or services that address new or traditional challenges. Let us see some of these examples in sequence.

Neptuno Pumps quickly realized that significant amounts of energy

\footnotetext{
${ }^{10}$ Muki is a micro-jumbo of $1.05 \mathrm{~m}$ width created to face narrow veins and to withstand the high temperatures, lack of water, excessive corrosion, humidity and high altitude of underground mining.
}

could be saved if pumps - in principle a standard product - were adapted to the specific geographical conditions. Thus, by adapting pumps to high altitude and aggressive waters, the company developed a product that allowed energy savings of up to USD 650,000 a year. A similar case is that of Power Train Technologies, that develops and sells diesel engines and other engines adapted for trucks that operate at high altitudes and extreme weather conditions. As pointed out by the company managers, engines developed by large MNCs do not work in these conditions, and the MNC would not find it profitable to invest and adapt its engines. The engines adapted by the local Chilean supplier managed to deliver a product that saves up to $10 \%$ in fuel consumption, improves performance and reduces carbon prints.

One of the most successful upgrading firms is Resemin which is a leading global supplier of drilling equipment in the underground mining equipment sector in Peru (Bamber et al., 2016, Box 4). The company's upgrading trajectory began as parts supplier, shifting to parts manufacturer, followed by final equipment production, using reverse engineering and finally own engineering for new equipment design. The specific conditions of mining in certain areas of Peru, where veins are very thin and the climate conditions extreme, favored Resemin's upgrading process.

Drillco Tools develops percussion hammers and drills specially adapted to the type of rock where they are used. In the early 1990s the company realized developing customized products was required to enter the MGVC. Interestingly, the company started adapting products to the specific conditions of Chile, but currently, and with the same approach, it sells hammers and drills, through its subsidiaries in Brazil, United States, Peru, Italy and South Africa (Stubrin, 2018). The firm exports $77 \%$ of its production, ad offers an interesting case of upgrading into a different MGVC. Linkages with clients to understand the specific requirements prevailing in each location were crucial.

Examples of new ventures opening new segments and developing new products and services include Aguamarina, High Service, Aplik, MICOMO, Geoambiente, and Verti. High Service from Chile produces remote monitoring and wireless communication, with new information technologies that did not exist before, thereby exploiting a new technological opportunity. Similar are the cases of MICOMO and Aplick, that produce monitoring mining operations and environmental forecast services. Verti, a university spinoff, provides highly specialized R\&D services to target a new market niche, that is adaptation of products and process to environmental regulations and demands. For instance, the company has developed new ways of recycling waste and screens (Figueiredo and Piana, 2016). Similarly, Terravision provides consulting services, licensing and environmental monitoring.

All the firms share a characteristic of substantial levels of investment in advanced levels of scientific and technological capabilities. They all perform R\&D and carry out other high level innovative efforts. The new firms entering the business typically start with a R\&D unit, whilst the incumbents have re-structured recently to give priority to R\& $\mathrm{D}$ and innovative activities. Moreover, they have often been created by a group of professionals with different but complementary backgrounds. An excellent example is Exsa from Peru that in 2013 created the office of Innovation Management in order to better target clients' needs. The company institutionalized a new client-oriented process to have a more direct channel of communication with clients. They conduct interviews with the CEOs of several mining companies to help them identify their main needs and align the company's innovation objectives with those of their clients through various forms, like for example periodical "Innovative Breakfasts" (Molina, 2018). Examples from Brazil also reveal that learning linkages with mining companies, notably Vale, and with Universities, have been instrumental in orienting the innovation efforts of new ventures in the business (Figueiredo and Piana, 2018).

Our original evidence suggests that these firms carried out substantial investments in innovation. Thus, many suppliers from Chile invest on average almost one quarter of their sales on innovative 
activities, and employ around $40 \%$ of their total employees in R\&D (Stubrin, 2018). In Peru the interviewed firms declared to employ between $3 \%$ and $4 \%$ of their total labor force in R\&D (Molina et al., 2016), perhaps due to their being in general older and larger than many Chilean cases. Many of these firms have also obtained substantial innovative inputs: Out of the eight companies from Peru, three have managed to introduce an innovation "new to the world", four an innovation "new to the local market", and one an innovation "new to the firm". Some of these innovations have been patented, both in the national and international markets. All firms interviewed in Chile developed innovations new to the world, eight out of nine applied for patents and seven also obtained national and international awards. Moreover, two of the Brazilian firms interviewed diversified to completely unrelated sectors (Figueiredo and Piana, 2018).

In sum, it appears that many of the examples studied in details have achieved remarkable levels of innovative technological capabilities. However, several of these firms are facing difficult challenges related to the management of their integration into the MGVC and to the creation of their own markets, to take full advantage of the innovations developed. Both forms of market access require unique and knowledge-based solutions where firms need to develop the conditions for the transaction to occur; obtain permission and the space to experiment with the new technology; and establish the conditions for the transaction, the contracts, agree on the value of the innovation, establish the rules of the game, and negotiate the distribution of benefits. This is still incipient in many instances, and is hindered by the hierarchical and conservative governance of the MGVCs discussed above.

\section{Conclusions and questions for future research}

The evidence discussed here and presented in the details of each specific country in the papers contained in this Special Issue confirms many of the theoretical expectations discussed in this paper. Thus, the quantity of demand is clearly becoming an important opportunity for innovation in mining value chains. The challenges that the industry is facing (e.g. decreasing ore grades, increasing incidence of local specificities, decreasing productivity and increasing costs, pressing social and environmental requirements) pose remarkable demands on local providers.

However, we also detected evidence that these challenges are rarely adequately translated into concrete demands to local suppliers, and that there appears to be a persisting communication failure that is overcome only occasionally.

Moreover, the potential for learning and innovation by suppliers tends to be limited and constrained by the industrial organization and the governance in most MGVCs. The hierarchical governance that tends to prevail does not promote quality linkages between lead firms and suppliers, with consequently little impact on suppliers' learning and innovation. We could detect how formal and informal interactions help suppliers identify lead-firms' demands, but they do not help in developing a solution in the form of a new or adapted product, process or organization. Lead firms tend to rely on established first-tier suppliers and prefer them to newcomers. Some new suppliers eventually capture the information on what the lead firm demands, develop solutions in isolation and with no room for testing, and take the burden of costly search, experimentation and testing before possibly fulfilling the lead firm's demand.

The incentives coming from the quality of demand and linkages are not therefore very strong. We identified instead that incentives for innovation and entry coming from supply played an important role. Indeed, the evidence showed that significant technological opportunities are emerging related to the recent advances in technologies, that are often science-based and applicable to the value chain. Thus, for example ICT is prompting new developments of remote control systems for trucks, and remote monitoring and wireless communication that allows predicting wear points in key equipment. Developments of new materials allow upgrading materials and applying advanced engineering to develop pumps capable to operate in special conditions (e.g. very dry climates and $4500 \mathrm{~m}$ above the sea level), and robots also open additional opportunities.

However, this potential is only being exploited by a handful of local firms, that developed strong scientific and technological capabilities and opened specific channels of communication with lead firms and large first-tier providers. Market entry has often occurred in two ways: either incumbent firms and established suppliers improving existing solutions (product and services) to old problems, benefiting from location specificities; or new firms and university spin-offs developing new products and processes that address specific challenges. The analysis carried out so far attempted to use different approaches to study the potential offered by the mining sector for local suppliers' learning and innovation. We blended in an original way the insights coming from different branches of literature, combining the insights from the study of scientific discoveries applied to mining, with the theory of entrepreneurship and capabilities creation, and with the GVC approach with its emphasis on inter-firm linkages and their governance, to conduct this exploratory study. Many research challenges remain open and deserve attention in the future. Thus, the capabilities complementary to production and necessary for market access and GVC integration need to be better understood. Similarly, the role of the various tiers of suppliers and their relationships with other local providers deserves future research. The role of public policies also needs to be explored in much greater details in a context characterized by remarkable uncertainties and by the coexistence of many actors with different and sometimes potentially clashing interests. These include civil society and the longterm interests of sustainability and environmentally sound management of the resource, lead-firms and their tiers of suppliers, and the intergenerational distribution of costs and opportunities deriving from the mining industry.

\section{References}

Andersen, Allan Dahl, 2012. Towards a new approach to natural resources and development: the role of learning, innovation and linkage dynamics. Int. J. Technol. Learn., Innov. Dev. 5 (3), 291-324.

Arias, M., Atienza, M., Cadenmatori, y.J., 2014. Large mining enterprises and regional development in Chile. J. Econ. Geogr. 14, 73-95.

Bamber P., Fernandez-Stark K., Gereffi G., 2016. Peru in the Mining Equipment Global Value Chain. Opportunities for Upgrading, January, available at $\langle$ https://gvcc.duke. edu>, (Accessed 26 April 2018).

Bell, M.R., Pavitt, K., 1993. 'Technological accumulation and industrial growth: contrasts between developed and developing countries'. Ind. Corp. Change 2 (2).

Benavente J.M. Goya, yD., 2011. Copper mining in Chile, Sectorial Report, Project Opening up Natural Resource-Based Industries for Innovation: Exploring New Pathways for Development in Latin America, IDRC

COCHILCO, 2015. Yearbook: Copper and other Mineral Statistics 1995-2014.

Bravo-Ortega, Muñoz, L., 2015. Knowledge Intensive Mining Services in Chile, IDB mimeo.

Crespi, G., Katz, J., Olivari, y.J., 2016. Innovación, actividades basadas en recursos naturales y cambio estructural: La emergencia de empresas de servicios intensivos en conocimiento. In: Navarro, J.C., Olivari, y.J. (Eds.), La Política de Innovación en América Latina y el Caribe: Nuevos Caminos, Capítulo 5. Banco Interamericano de Desarrollo, Washington D.C..

Cutler T., 2012. The Australian experience of innovation driving productivity and competitiveness in the mining sector presented in Cochilco Seminar, Santiago Chile, December.

Dantas, E., 2011. The evolution of the knowledge accumulation function in the formation of the Brazilian biofuels innovation system. Int. J. Technol. Glob. 5 (3-4), 327-340.

ECA, 2013. Making the Most of Africa's Commodities: industrializing for Growth, Jobs and Economic Transformation, Economic Report on Africa. United Nations Economic Commission for Africa, Addis Ababa. 〈https://www.uneca.org/sites/default/files/ PublicationFiles/unera_report_eng_final_web.pdf> (Accessed May 9, 2018).

Farooki, M., 2012. The diversification of the global mining equipment industry-Going new places? Resour. Policy 2012.

Farole, T., Winkler, D., 2014. Making foreign direct investment work for Sub-Saharan Africa: local spillovers and competitiveness in global value chains. World Bank Publications.

Fessehaie, J., 2012. What determines the breadth and depth of Zambia's backward linkages to copper mining? The role of public policy and value chain dynamics. Resour. Policy 37 (4), 443-451.

Figueiredo, P.N., Piana, J., 2018. Innovative capability building and learning linkages in new entrant knowledge-intensive service SMEs in the mining industry: evidence from 
Brazil. Resour. Policy (Forthcoming).

Figueiredo, P.N., Piana, J., 2016. When "one thing (almost) leads to another": a microlevel exploration of learning linkages in Brazil's mining industry. Resour. Policy. http://dx.doi.org/10.1016/j.resourpol.2016.07.008.

Frances, E., 2015. The Australian Mining Industry: More than Just Shovels and Being the Lucky Country. The Government of Australia, IP Australia.

Fundación Chile, 2014. Proveedores de la minería chilena. Estudio de caracterización 2014, 〈www.fundacionchile.cl〉.

Gereffi, G., Humphrey, J., Sturgeon, T., 2005. The governance of global value chains. Rev. Int. Political Econ. 12 (1), 78-104.

von Hippel, E., 1976. The dominant role of users in the scientific instrument innovation process. Res. Policy 5, 212-239.

Humphreys, M., Sachs, J.D., Stiglitz, J.E., 2007. Escaping the Resource Curse. Columbia University Press, New York.

ICMM - International Council on Mining and Metals, 2014a. The role of mining in national economies (2nd edition).

Iizuka, Michiko, Katz, Jorge, 2015. Globalization, sustainability and the role of institutions: the case of the Chilean salmon industry. Tijdschr. voor Econ. En. Soc. Geogr. http://dx.doi.org/10.1111/tesg.12132.

Hirschman, A.O., 1958. The Strategy of Economic Development. Yale University Press, New Haven, Conn.

Kaplan, D., 2012. South African mining equipment and specialist services: technological Capacity, export performance and policy. Resour. Policy 37, 425-433. http://dx.doi. org/10.1016/j.resourpol.2012.06.001.

Kaplinsky, R., Morris, M., 2016. Thinning and thickening: productive sector policies in the era of global value chains. Eur. J. Dev. Res., Sept. 28 (4), 625-645. http://dx.doi. org/10.1057/ejdr.2015.29.

Katz, J., Pietrobelli, C., 2018. "Natural resource-based growth, global value chains and domestic capabilities in the mining industry". Resour. Policy (Forthcoming).

Klevorick, A.K., Levin, R.C., Nelson, R.R., Winter, S.G., 1995. On the sources and significance of inter-industry differences in technological opportunities. Res. Policy 24, $185-205$.

Korinek, J., 2013. Mineral Resource Trade in Chile: Contribution to Development and Policy Implications, OECD Trade Policy Papers, No. 145, OECD. http://dx.doi.org/ 10.1787/5k4bw6twpf24-en.

Lall, S., 1992. Technological Capabilities and Industrialization. World Dev. 20 (2).

Laursen, K., 1999. The impact of technological opportunity on the dynamics of trade performance. Struct. Change Econ. Dyn. 10 (3-4), 341-357.

Lundvall, B.-A., 1988. Innovation as an Interactive Process: From User Producer Interaction to National systems of Innovation. In: In: Dosi, G. (Ed.), Technical Change and Economic theory Pinter Publisher.

Glade, M., Kuramoto, J., 2007. La minería peruana. Lo que sabemos y lo que aún nos falta por saber (chapter 4) In: ed. 1. Investigación, Políticas y Desarrollo en el Perú 1. Grupo de Análisis para el Desarrollo (GRADE), pp. 135-181.

Marin, A., Van Zwanenberg, P., 2015. Transitions, structural change and development: transforming natural resource-based industries in Latin America. Paper presented at In: Proceedings of the International Sustainability Conference 2015.

Marin, A., Navas-Aleman, L. y., Perez, C., 2015. Natural resource industries as a platform for the development of knowledge intensive industries. Tijdschr. Voor Econ. En. Soc. Geogr. 106 (2).

Marin, A., Dantas, E.y. Obaya, M., 2016. Alternative technological paths in new NR-related industries: the case of seeds in Argentina and Brazil, under revision for World Development. 〈http://www.fund-cenit.org.ar/alternative-technological-paths-innew-nr-related-industries-the-case-of-seeds-in-argentina-and-brazil/publicacion/ 392/es>.

Marin, A. y., Petralia, S., 2018. Sources and contexts of inter-industry differences in technological opportunities: the cases of Argentina and Brazil. Innov. Dev. 8 (1)).

Meller, P., Gana, J., 2015. El cobre chileno como plataforma de innovación tecnológica. CIEPLAN, Santiago.

McKinsey Company, 2013. An assessment of the competitiveness and health of Peru's mining industry. McKinsey.
Molina, O., 2018. "Innovation in an unfavorable context: local mining suppliers in Peru". Resour. Policy (Forthcoming).

Molina O., Olivari J., Pietrobelli C., 2016. Global Value Chains in the Peruvian Mining Sector, Inter-American Development Bank IDB-TN-1114 〈http://dx.doi.org/10. 18235/0000468>.

Morris, M., Kaplinsky, R., Kaplan, D., 2012. One things lead to another- commodities, linkages and industrial development. Resour. Policy 37, 408-416.

Morrison, A., Pietrobelli, C., Rabellotti, R., 2008. Global value chains and technological capabilities: a framework to study learning and innovation in developing countries. Oxf. Dev. Stud. 36 (1), 39-58. http://dx.doi.org/10.1080/13600810701848144.

Navarro L., 2018. The World Class Supplier Program for Mining in Chile: Assessment and Perspectives, mimeo, forthcoming.

Nelson, R., Winter, S., 1982. An Evolutionary Theory of Economic Change. The Belknap Press of Harvard University Press, Cambridge, Massachusetts.

OECD, 2005. Knowledge intensive Service Activities in the Mining Technology Services Industry in Australia, KISA Project.

Ovadia, J.S., 2014. Local content and natural resource governance: the cases of Angola and Nigeria. Extr. Ind. Soc. 1 (2), 137-146.

Pérez, C., 2010. Technological dynamism and social inclusion in Latin America: a resource- based development strategy. CEPAL Rev. 121-141 (N 100).

Pietrobelli, C., Rabellotti, R., 2007. Upgrading to Compete. Global Value Chains, SMEs and Clusters in Latin America. Harvard University Press, Cambridge Ma.

Pietrobelli, C., Rabellotti, R., 2011. Global value chains meet innovation systems: are there learning opportunities for developing countries. World Dev. 39 (7), 1261-1269.

Prebisch, R., 1950. The economic development of Latin America and its principal problems. Econ. Bull. Lat. Am. 7, 1-12.

Sachs, J.D., Warner, A.M., 2001. Natural resources and economic development. The curse of natural resources. Eur. Econ. Rev. 45, 827-838.

Schmookler, J., 1950. Invention and Economic Growth. Harvard University Press.Singer, Cambridge MA.

Scott-Kemmis, D., 2013. How about those METS? Leveraging Australia's mining equipment, technology and services sector. Min. Counc. Aust.

Segal, N., 2000. The South African mining industry in the 21st century. Chamb. Mines South Afr.

Singer, H., 1950. Comments to the terms of trade and economic development. Rev. Econ. Stat. 40, 84-89.

Stubrin, L., 2018. "Innovation, learning and competence building in the mining industry. The case of knowledge intensive mining suppliers (KIMS) in Chile". Resour. Policy (Forthcoming).

Teece, D., 1986. Profiting from technological innovation: implications for integration, collaboration, licensing and public policy. Res. Policy 15 (6), 285-305.

Teece, D., Pisano, G., Shuen, A., 1997. Dynamic capabilities and strategic management. Strateg. Manag. J. 18 (7), 509-533.

Urzúa, O., 2011. The Emergence and Development of Knowledge Intensive Mining Service Suppliers in the Late 20th Century. A University of Sussex DPhil thesis.

Venables, A.J., 2016. Using natural resources for development: why has it proven so difficult? J. Econ. Perspect. 30 (1), 161-184. http://dx.doi.org/10.1257/jep.30.1. 161.

Ville, S., Wicken, O., 2012. The dynamics of resource-based economic development: Evidence from Australia and Norway. Ind. Corp. Change 22 (5).

\section{Further reading}

Accenture, 2011. Global Operating Models for Mining Companies Mining Executive Series.

Martínez-Fernandez, M.C., 2005. Knowledge-Intensive Services Activities (KISA) in Innovation of the Mining Technology Services Sector in Australia. University of Western Sydney. 